\title{
Erialane hübriididentiteet praktikute-õppejõudude arusaamades
}

\author{
Elina Reva ${ }^{\mathrm{a} 1}$, Marvi Remmik ${ }^{\mathrm{b}}$ \\ ${ }^{a}$ SA Põhja-Eesti Regionaalhaigla, Tallinna Tervishoiu Kõrgkool \\ ${ }^{b}$ Tartu Ülikooli Johan Skytte poliitikauuringute instituut ja \\ Tartu Ülikooli Viljandi kultuuriakadeemia
}

\begin{abstract}
Annotatsioon
Kõrgkoolide erialaõppes on kvaliteetse hariduse pakkumisel oluline, et õppetöösse oleksid kaasatud ka erialal töötavad spetsialistid. Mitmes rollis töötamine nõuab praktikutelt-õppejõududelt mitmekesiseid teadmisi ja oskusi, mistõttu kasutatakse kahe eriala - õpitud eriala ning õpetaja - teadmisi ja oskusi. Uuringu eesmärk on analüüsida praktikute-õppejõudude erialast hübriididentiteeti ja sellega seonduvaid tegureid. Uuringus intervjueeriti 18 praktikut-õppejõudu. Andmeid analüüsiti kvalitatiivse sisuanalüüsi meetodil. Tulemused osutasid, et praktikute-õppejõudude arusaamades väljenduv erialane hübriididentiteet on kaldu nn õpitud eriala identiteedi poole, samas õppejõu identiteet on pigem tagaplaanil. Tugev erialasesse kogukonda kuuluvuse tunne ja vähene õppejõudude kogukonda kuuluvus on praktikute-õppejõudude hübriididentiteedi kujunemisel määrava tähtsusega.
\end{abstract}

Võtmesõnad: praktikud-õppejõud, erialane identiteet, erialane hübriididentiteet, kvalitatiivne uurimus

\section{Sissejuhatus}

Eesti kõrgharidus muutub koos Euroopa Liidu arengusuundumustega. Sellest tulenevalt on praktilise väljundiga erialadel, nagu õdede, politseinike, tehniliste erialade väljaõpe järjest enam kasvanud vajadus kaasata õppetöösse praktikuid, kes oleksid kõrgkoolides võimelised tegema kvaliteetset õppetööd. Varasemate uuringute kohaselt oodatakse õppejõult eelkõige häid õpetamisoskusi, võimet seostada teooriat praktikaga, arendada õppijate isiksuslikke omadusi ja toetada õpiväljundite saavutamist (Brower, Humphreys, Karoff, \& Kallio, 2017; Fairbrother \& Ford, 1998, 2004; Gonzales \& Wagenaar, 2008). Seega eeldab õpetamine praktikutelt võimet määratleda ennast nii eriala asjatundjate kui ka õppejõududena. 
Igasugune erialane identiteet kujuneb õpingute, töökogemuse ja keskkonna koosmõjul (Gibson, Dollarhide, \& Moss, 2010), mistõttu on praktikud-õppejõud hübriididentiteedi kandjad, kus peale õpitud eriala identiteedi väljendub ka teine - õppejõu identiteet (Colley \& Guery, 2014). Artiklis keskendutakse praktikutele-õppejõududele, kellena mõistetakse erialal töötavaid spetsialiste, kes samal ajal õpetavad kõrgkoolide õppekavadel.

Kuna õpetamispraktika edukus sõltub õppejõu identiteedist, selle kujunemisest ja väljendumisest (Robinson \& McMillan, 2006), võib praktikutel-õppejõududel, kes jätkavad tööd oma erialal ning samal ajal õpetavad kõrgkoolis, olla unikaalne, mitmest erialasest rollist mõjutatud identiteet. Praktikuteõppejõudude õpetamispraktikas mõjutab niisugune hübriididentiteet üliõpilaste tulevasi tööalaseid oskusi, teadmisi, arusaamu ja ka üliõpilaste endi tulevast erialast identiteeti. (Fairbrother \& Ford, 1998; Gonzales \& Wagenaar, 2008). Õpetamisel suunavad praktikud-õppejõud üliõpilasi vajalike erialaste baasteadmiste poole, kujundavad praktilisi oskusi ja loovad oma suhtumise ning isikliku eeskujuga erialakuvandit (Fejes \& Köpsten, 2014; Robinson \& McMillan, 2006). Õpetamisarusaamu käsitlevad uuringud (Reva, Karm, Lepp, \& Remmik, 2014) osutavad, et õppejõudude õpetamisoskuste arendamisele pööratakse kõrgkoolides tähelepanu, samas on õppejõudude erialase identiteedi teadlik mõtestamine samavõrd tähtis (Poom-Valickis \& Löfström, 2014).

Kuigi õppejõudude identiteedi teemat käsitletakse uuringutes üsna laialdaselt (nt Fejes \& Köpsen, 2014; Levin \& Shaker, 2011; Robinson \& McMillan, 2006), on praktikute-õppejõudude erialase identiteedi teema pälvinud vähem tähelepanu (nt Hope, 2018; Levin \& Hernandez, 2014; Masri, 2018). Praktikute-õppejõudude erialase identiteedi olemuse mõistmine võimaldab neid toetada tööalase arengu kontekstis. Seega vajab samal ajal erialal töötavate ning kõrgkoolis õpetavate spetsialistide õpetamispraktika endiselt tõenduspõhist uurimist (Dall'Alba, 1994; Fitzmaurice, 2013; Reva et al., 2014).

Mõistmaks praktikute-õppejõudude erialase hübriididentiteedi kujunemist ja selle arendamise võimalusi, antakse järgnevalt ülevaade erialase identiteedi (sh hübriididentiteedi) olemusest ja selle kujunemise teoreetilistest käsitlustest.

\section{Erialane ja hübriididentiteet}

Uurijad on seisukohal, et identiteedi mõiste tähendusväli on avar (nt Brubaker \& Cooper, 2000; Jenkins, 2000), mõiste piirid ähmased ning sisu suhtes puudub üksmeel (Ehala, 2018). Eri teadusharudes on identiteedi mõistel isesugune kujunemislugu, samuti võivad erineda selle käsitlemise traditsioonid. 
Erialase arengu kontekstis räägitakse peamiselt inimeste rollidega seotud identiteetidest, sealhulgas erialasest ja hübriididentiteedist (Stets \& Burke, 2000; Stryker \& Burke, 2000). Järgnevalt keskendutakse erialase ja hübriididentiteedi olemuse selgitamisele.

Erialast identiteeti käsitletakse sageli tähenduste kogumina, mida inimesed endale kogukonna liikmena ametialases rollis omistavad. Mitmes uuringus (Stets \& Burke, 2000; Stryker \& Burke, 2000; Luke \& Goodrich, 2010) on leitud, et erialane identiteet on eneseteadlikkuse väljendus, mis kujuneb kognitiivsete protsesside ja psühholoogiliste ressursside toel ning on seotud sotsiaalsete rollide ning keskkonnaga. Seega on erialane identiteet seotud ka eneseanalüüsiga (Beijaard, Meijer, \& Verloop, 2004, lk 113-122).

Tuginedes Goltzi ja Smithi (2014) erialase identiteedi tõlgendusele, on erialane identiteet seotud nii väliste ehk sotsiaalsete kui ka sisemiste ehk personaalsete mõjutavate teguritega. Sotsiaalselt mõjutavad erialast identiteeti ühiskondlikud normid, ootused ja riiklikud regulatsioonid, nagu õppekavad ja erialadele esitatud pädevusnõuded. Personaalselt on mõju seotud isiksuse eneseteadlikkuse ja erialase rolli kujutlusega, milleks on näiteks isiksuseomadused või valdkonnapõhised kogemused. Oluliseks peetakse erialase identiteedi arengus personaalsete ja sotsiaalsete mõjutajate tasakaalu, et kindlustada eriala sotsiaalne tunnustus ja mõjusus ühiskonnale (Murray, 2013). Identiteedi mõju käitumisele väljendub sotsiaalses interaktsioonis, lähtub isiklikest arusaamadest ja tähenduste loomise oskusest (Styker \& Burke, 2000).

Seega on erialast identiteeti oluline vaadelda mitte ainult ühe eriala väärtuste ja kompetentside raamistikus, vaid ka selles, kuidas suhestutakse teiste eriala esindajatega (Nygren \& Stigbran, 2014). Niisiis mõistetakse erialast identiteeti pidevalt muutuva, dünaamilise protsessina ehk tegelikkusena, mis areneb individuaalsel ja sotsiaalsel tasandil (Correa, Martinez-Arbelais, \& Gutierres, 2014; Marcelo, 2009; Stryker \& Burke, 2000) ning mille eelduseks on alati personaalsed ning sotsiaalsed tingimused (Crossley \& VivekanandaSchmid, 2009; Goltz \& Smith, 2014). Erialane identiteet väljendub suhtlemisel, tööalase positsiooni ja kogemuste kontekstis (Johnson, Cowin, Wilson, \& Young, 2012). Sellega seonduvad erialased tähendused ja ootused, samuti erialaga seotud arusaamad, tunded ja tegevused (Johnson et al., 2012; Shreeve, 2011; Stryker \& Burke, 2000; Van Lankveld et al., 2016; Warin, Maddock, Pell, \& Hargreaves, 2006).

Erialase identiteedi teooriad toovad esile peamiselt kolm erialase identiteedi väljendumise tunnust: esiteks eriala kontekstis toimuv eneseanalüüs, teiseks seotus eriala kogukonnaga, kolmandaks isikliku ja erialase maailmavaate seotuse väljendamine (Gibson, Dollarhide, \& Moss, 2010). Luke ja Goodrich (2010) ning Slay ja Smith (2010) leiavad, et isikliku ja erialase mina 
omavaheline seos väljendub üksteist täiendava või vastuolulise info lõimimisel. Monrouxe (2010) lisab, et erialase identiteedi kujunemisel õpitakse eristuma teistest erialade esindajatest.

Erialase arengu kontekstis räägitakse ka hübriididentiteedist (Goltz \& Smith, 2014), mis kujuneb kahe või mitme olulise erialase rolli liitumisel üheks tervikuks ning kus rollid omakorda kannavad erinevaid identiteete (Shreeve, 2009; Stryker \& Burke, 2000). Nii leitaksegi, et õppejõu rollis olevad praktikud kannavad endas vähemalt kahte identiteeti: õpitud eriala ja sellele lisanduvat õppejõu identiteeti. Kaks identiteeti on omavahel põimunud erialateadmiste ja -oskuste ning praktikas saadud kogemuse seoses (Reybold, 2008). Samuti võib erialase hübriididentiteedina mõista ka nn kraadiidentiteeti ja pädevusidentiteeti (Goltz \& Smith, 2014). Kraadiidentiteet on mitme eriala teaduskraadi omandamise tulemusel kujunenud hübriididentiteet, pädevusidentiteedi korral räägitakse mitme ametiga seotud hübriididentiteedist.

Erialane identiteet on pidevas muutumises ning selle kujunemine algab erialakogukonna liikmeks saamisega sotsiaalses kontekstis - õppides ja suheldes (Van Lankveld et al., 2016; Slay \& Smith, 2010; Stets \& Burke, 2000; Stryker \& Burke, 2000). Erialast identiteeti võib mõista pideva taasloomise protsessina, kus on oluline ka arusaamine erialasest tulevikuperspektiivist. Kuigi erialase identiteedi kujunemise alguseks võib olla ka juba enne erialaõpinguid teadvustatud info ja fragmentaarsed kogemused (Johnson et al., 2012), peab enamik erialase identiteedi uurijaid identiteedi peamisteks kujundajateks endiselt erialaõpinguid, sealhulgas nende kestust, sisu, mahtu (Goltz \& Smith, 2014; Helmich et al., 2010; Nygren \& Stigband, 2014). Eraldi rõhutatakse erialase identiteedi kujunemisel seoseid praktilise õppega töökeskkonnas (Crossey \& Vivekananda-Schmidt, 2009; Gibson et al., 2010; Goltz \& Smith, 2014).

Hübriididentiteedi kujunemist iseloomustab, et ühe eriala identiteedile omased käitumisviisid domineerivad seni, kuni teine erialane identiteet alles areneb (Warin et al., 2006). Nii ongi hübriididentiteet erialaste identiteetide muutumise protsess, teatud psühholoogiline dissonants mitme erialase identiteedi vahel, mida võidakse kogeda ka ebamugavust tekitava olukorrana (Warin et al., 2006).

Praktiku-õppejõu hübriididentiteedi kujunemine võib olla lõhestatud kahe erineva töökultuuri seostamise ja erinevustega leppimise vajaduse tõttu, mis eeldab psühholoogilist ja sotsiaalset toetust. Näiteks leidsid Gourlay (2011) ja Shreeve (2011), et kõrgkoolis õppetööd alustanud meditsiinivaldkonna praktikud-õppejõud ei tundnud end õppejõudude kogukonda kuuluvana, vaid pigem eraldatuna. Praktikud-õppejõud tajusid erinevust ametialaste tavade ja varasemate rollide ning uuel akadeemilisel ametikohal töötamise vahel. Kui varasematel ametikohtadel olid praktikud-õppejõud tunnistajaks 
kollektiivsusele ja koostööle, siis akadeemilised ametikohad osutusid individualistlikuks ja privaatseks. Uues kontekstis nägid kõrgkoolides tööd alustanud praktikud-õppejõud end kõrvaliste ja ebakindlate amatööridena (Gourlay, 2011). Sarnasele tulemusele jõudis oma uuringus ka Masri (2018), kelle uuring näitas, et praktikute-õppejõudude õppetöö toimub teatavas eraldatuses, mis on osaliselt põhjustatud ka praktikute-õppejõudude vähesest seotusest kõrgkooliga. Kõrgkooli toetuse puudumine mõjutab hübriididentiteedi kujunemist ehk identiteetide kinnitusprotsesse (nt Stryker \& Burke, 2000) ja see võib lõppeda õppejõutööst loobumise ning edaspidi ainult erialase praktikaga tegelemisega (Smith \& Boyd, 2012). Enamasti näitab õppejõuna tegevuse lõpetamine, et praktiku-õppejõu identiteedi areng on jäänud toetuseta (Shreeve, 2011). Smithi ja Boydi (2012) uuring näitas, et praktikud-õppejõud tajuvad oma erialases hübriididentiteedis teatavat vastuolu ning peavad kahe erineva rolli täitmist keeruliseks ja kurnavaks, mis annab kinnitust sellest, et eri rollid võivad vajada ka erisugust toetust.

Seega võib erialast identiteeti mõista pidevalt muutuva arusaamana erialastest rollidest, kompetentsist ja väärtustest. Sügava erialase identiteedi indikaatoriks peetakse suhestumist teiste eriala esindajatega ja eneseanalüüsi võimet, millest annab märku kuuluvuse, seotuse ja uskumuste väljendumine tegevustes, arusaamades, väärtustes ja sümbolites (Luchmann, 2007; Slay \& Smith, 2010). Kuna erialane identiteet on alati subjektiivne ja dünaamiline, on ka iga indiviidi erialane identiteet omanäoline.

Kokkuvõttes võib öelda, et teadlikkus praktiku-õppejõu hübriididentiteedi olemusest on ópetamispraktika kontekstis oluline nii tulevaste eriala asjatundjate identiteedi kujundamisel kui ka praktikute-õppejõudude endi erialase hübriididentiteedi arengu toetamisel. Erialase identiteedi kujunemine on pidevalt muutuv protsess, kuid see avaldab olulist mõju nii erialasele kui ka õpetamispraktikale. Selleks, et arendada praktikute-õppejõudude õpetamispraktikat nende identiteedi kujundamise kaudu, on vaja mõista praktikuteõppejõudude erialast (hübriid)identiteeti ja sellega seotud tegureid nende arusaamades.

Siinse uuringu eesmärk on analüüsida praktikute-õppejõudude erialast hübriididentiteeti ja sellega seonduvaid tegureid praktikute-õppejõudude vaatepunktist. Eesmärgist tulenevalt otsiti vastuseid järgmistele uurimisküsimustele:

1) Millisena väljendub erialane hübriididentiteet praktikute-õppejõudude arusaamades?

2) Milliseid hübriididentiteedi kujunemist mõjutavaid tegureid praktikudóppejõud oma arusaamades väljendavad? 


\section{Metoodika}

\section{Valim}

Uuring tehti 18 praktiku-õppejõuga, kes igapäevase erialase töö kõrvalt õpetavad ka Eesti rakenduskõrgkoolides sotsiaal-, tervishoiu- ja tehnikavaldkonnas. Valim moodustati sihipäraselt ja uuritavate leidmisel oli kriteeriumiks uuritava töötamine erialal ja samaaegne õpetamine kõrgkoolis. Valimisse kuulusid politsei, õigusteaduse, kommunikatsioonijuhtimise, õenduse, logistika, mehaanika ja liikluskorralduse eriala praktikud-õppejõud. Andmekogumise ajal olid uuritavad põhikohaga tööl oma erialal ja õpetasid osalise tööajaga. Uuritavate erialal töötamise kogemus varieerus 3-45 aastani, õpetamiskogemus kõrgkoolis 0,5-45 aastani. Praktikute-õppejõudude õpetamiskoormus kõrgkoolis oli keskmiselt 78 akadeemilist tundi õppeaastas.

\section{Andmekogumine}

Andmete kogumiseks tehti praktikute-õppejõududega poolstruktureeritud intervjuud. Poolstruktureeritud intervjuu võimaldab uurijal küsida intervjuu käigus lisaküsimusi, et saada teema kohta sügavamat ja sisukamat infot, ning annab intervjueeritavatele võimaluse vabalt oma mõtteid väljendada. Täpsustavate küsimuste esitamine intervjuude käigus oli oluline, sest iga intervjueeritava kogemused on omanäolised ning seetõttu ei olnud võimalik kõiki küsimusi enne intervjuud täpselt ette mõelda. Varasematele uuringutele tuginedes (nt Johns, 2004; Smith \& Boyd, 2012) koostati poolstruktureeritud intervjuu kava, milles keskenduti praktikute-õppejõudude õpetamispraktikale ehk nende kogemustele õppejõuna õpitud eriala põhjal. Peale esialgse intervjuu kava koostamist paluti soovitusi küsimuste täpsustamiseks ja täiendamiseks valdkonna ekspertidelt ning muudatuste sisseviimise järel tehti prooviintervjuu kahe praktiku-õppejõuga. Prooviintervjuu järel märkimisväärseid muudatusi intervjuu kavas ei tehtud.

Intervjuu koosnes järgmistest teemaplokkidest: 1) Õppejõuks saamise teekond (nt küsimus „Kuidas sai sinust õppejõud?"), 2) Õpetamise väärtus ja rollide täitmine (nt küsimused „Milles seisneb sinu jaoks õpetamise väärtus?“, „Mida praktiku ja õppejõu rolli täitmine sinu jaoks tähendab?“) 3) Õpetamise protsess, õpetamise teadvustamine ja mõju õppijatele (nt küsimused „Millised on tegevusmudelid, mida õpetamisel kasutad?“, „Kuidas on õpetamine sinu õppijaid mõjutanud?“, „Mida õpetamine sinu jaoks tähendab?“). Siinses artiklis käsitletakse teise ja kolmanda ploki teemasid.

Praktikuid-õppejõude intervjueeris artikli esimene autor. Kaks intervjuud toimus Skype'i vahendusel, ülejäänud 16 silmast silma. Intervjueerimisel 
peeti kinni eetikanõuetest: intervjueeritavat teavitati intervjuu eesmärkidest ja hilisemast andmete hoiustamisega seonduvast, intervjueeritava õigusest küsimustele vastamisest keelduda ja intervjuu katkestada; konfidentsiaalsuse tagamisega seonduvast ning hilisematest tegevustest tulemuste avaldamisel. Intervjuud kestsid 35-90 minutit. Kõik intervjuud transkribeeriti täies mahus ning transkribeeritud teksti ühe intervjuu kohta oli kokku keskmiselt seitse lehekülge.

\section{Andmeanaliüis}

Andmete analüüsimiseks kasutati kvalitatiivset deduktiivset sisuanalüüsi, mida juhtis teoreetiline ülevaade varasematest uuringutest ja uuringu tulemustest (vt Elo \& Kyngäs, 2008; Elo et al., 2014; Graneheim \& Lundman, 2004). Andmeanalüüsi aluseks loodi kirjanduse ülevaatele tuginev kategooriate raamistik ehk kodeerimisjuhend (vt tabel 1), mille alusel intervjuudest kodeeriti neid kõige enam kirjeldavad ja iseloomustavad tähendusüksused.

Andmeanalüüsi esimese etapina loeti intervjuusid mitu korda, et saada andmestiku sisuga detailideni tuttavaks. Lugemise käigus tehti esmaseid vabavormilisi märkmeid uurimisküsimuste seisukohast oluliste mõtete ja ideede kohta, luues sel viisil aluse kodeerimiseks. Järgnevas kodeerimise etapis märgistati analüüsiühik ehk uurimisküsimuse kontekstis tervikmõtet edasi andev lauseosa, lause või lõik, mis iseloomustas teooria põhjal loodud analüüsi aluseks olevat alakategooriat.

Usaldusväärsuse suurendamiseks analüüsisid mõlemad artikli autorid eraldi kõiki intervjuu tekste, et olla kindlad kodeerimise reliaabluses. Artikli esimene autor tegi ka korduvkodeerimise kogu andmestiku lõikes kuue kuu möödudes esmasest kodeerimisest, arutades (ja kooskõlastades) seejärel kodeerimistulemusi teise autoriga. Näide andmete analüüsi alusest ja kategooriaid iseloomustavatest tekstikatketest on esitatud tabelis 1 .

Uuringu ajal pidas esimene autor uurija päevikut, milles kajastas uuritavate emotsioone ja tunnete kirjeldusi intervjuu ajal. Päevikusissekanded on aidanud uurijatel tõlgendada uuringu tulemusi ja artikli aruteluosa esitamist.

Andmeanalüüsi tulemusel eristusid analüüsi aluseks olevate kategooriate kaupa järgmised iseloomustavad tähendusüksused: 1) uurimisküsimus: millisena väljendub erialane hübriididentiteet praktikute-õppejõudude arusaamades? (Kategooriad: seotus erialase ja õpetamistööga; erialase ja õpetamispädevuse teadvustamine; seotus eriala- ja õpetamisalase kogukonnaga), 2) uurimisküsimus: milliseid erialase (hübriid)identiteedi kujunemist mõjutavaid tegureid praktikud-õppejõud oma arusaamades väljendavad? (Kategooriad: erialase ja õpetamistööga seotud ühiskondlike normide ja ootuste 
mõju; erialase ja õpetamisalase töökogemuse tähendus; erialase ja õpetamisalase hariduse või ettevalmistuse olulisus). Järgnevalt esitatakse tulemused kategooriate ja alakategooriate kaupa.

Tabel 1. Erialase hübriididentiteedi tunnused ja kujunemisega seotud tegurid

\begin{tabular}{|c|c|}
\hline Erialase hübriididentiteedi väljendumine & $\begin{array}{l}\text { Hübriididentiteedi kujunemisega seotud } \\
\text { tegurid }\end{array}$ \\
\hline $\begin{array}{l}\text { Seotus erialase ja õpetamistööga } \\
\text { Erialane töö on olnud minu jaoks kirg ... Ehk siis } \\
\text { see valdkond mind ennast ka tõesti väga huvitab. } \\
\text { Ja mind huvitas ka ennast täiendada selles } \\
\text { valdkonnas ja seega ka siis neid teadmisi edasi } \\
\text { anda õpilastele. (B4) }\end{array}$ & $\begin{array}{l}\text { Erialase ja õpetamistööga seotud ühiskondlike } \\
\text { normide ja ootuste mõju } \\
\text { Sellisel juhul ma ei peagi võib olla sellele õppele } \\
\text { lähenema niivõrd kui õppejõud, vaid minus } \\
\text { saab rohkem avaneda mina kui ekspert, kes ma } \\
\text { ju tegelikult olen siia kutsutud ja oodatud oma } \\
\text { teadmisi jagama. Et seda ma olen tajunud ja } \\
\text { märganud küll õppeprotsessi juhina. (B6) }\end{array}$ \\
\hline $\begin{array}{l}\text { Erialase ja õpetamispädevuse teadvustamine } \\
\text { Ma ikka määratlen ennast hetkel küll pigem } \\
\text { praktikuna või sellise integraatorina, kes saab aru } \\
\text { nagu sellest akadeemilisest süsteemist, aga, kes } \\
\text { mõistab ka praktilist päriselu. Või pigem ma olen } \\
\text { sealt päriselu poole pealt, aga oskan võib-olla } \\
\text { siduda neid kahte asja (A6) }\end{array}$ & $\begin{array}{l}\text { Erialase ja õpetamistöö kogemus } \\
\text { Praktika on see, mis rõhutab kohakaaslasest } \\
\text { õppejõu väärtust, mina niimoodi arvan. Meil on } \\
\text { silmaring laiem, ma arvan, meil on pidev praktikast } \\
\text { tulevad värsked juhtumid, värsked mingid arutelud, } \\
\text { et see toob särtsu juurde õppuritele... (C3) }\end{array}$ \\
\hline $\begin{array}{l}\text { Seotus eriala- ja õpetamiskogukonnaga } \\
\text { See õpetaja osa on boonuseks pigem, ma ütlen } \\
\text { lihtsalt, et midagi ei juhtu ka, kui ma ei õpeta. } \\
\text { Aga ma saan ennast kuidagi teostada läbi selle } \\
\text { öpetamise. Määratlen ennast ikka ainult põhitöö } \\
\text { tegijana oma valdkonnas (C2) }\end{array}$ & $\begin{array}{l}\text { Erialane ja õpetamisalane ettevalmistus } \\
\ldots \text { o. ôpetamise teoreetilist tausta ei ole mina kuskil } \\
\text { mujal õppinud, ainult omal käel ... } \\
\text { Eneseharimise projekt nii-öelda (B3) }\end{array}$ \\
\hline
\end{tabular}

Aluseks: Gibson jt (2010); Goltz ja Smith (2014); Johnson jt (2012); Marotta (2008); Murray (2013); Nygren ja Stigband (2014); Shreeve (2009); Smith ja Boyd, (2012); Van Lankveld jt (2016); Warin jt (2006).

Artiklis esitatud intervjuukatkeid on vähesel määral parema mõistetavuse huvides toimetatud ning eemaldatud kordusi ja täitesõnu. Tsitaatidele järgnevad uuritavate nimedega mitte seotud tähe- ja numbrikombinatsioonid. Uuritavate konfidentsiaalsuse tagamise eesmärgil on tsitaatidest eemaldatud osalejate tegevusvaldkonnale või nende töö eripärale selgelt osutavad tunnused. 


\section{Tulemused}

\section{Praktikute-õppejõudude erialase hübriididentiteedi väljendumine}

Tulemuste analüüsimisel on välja toodud praktikute-õppejõudude arusaamades võimalikud hübriididentiteedile osutavad tunnused. Andmeanalüüsi käigus lähtuti erialast identiteeti iseloomustavatest uuritavate enesekohastest ja erialaga seotud seisukohtadest. Analüüsi juhtisid kolm kirjanduse ülevaate põhjal loodud kategooriat: seotus erialase ja õpetamistööga, erialase ja õpetamispädevuse teadvustamine ning seotus erialase ja õpetamisalase kogukonnaga.

\section{Seotus erialase ja õpetamistööga}

Kategooriat iseloomustasid uuritavate arusaamad, mis tõid esile tugeva seotuse erialase tööga. Oma esimest, n-ö õpitud eriala, millel kõik uuringus osalenud ka põhikohaga töötasid, rõhutati kõigi intervjuude vältel mitu korda. Õpetamisega seotust mainiti intervjuudes põgusalt. Erialast tööd peeti õppejõu töö aluseks või sisendiks. Praktikud-õppejõud väljendasid intervjuudes kirge oma erialase töö vastu ning pidasid ennast eriala asjatundjateks. Praktikuteõppejõudude arusaamad osutasid tugevale seotusele erialaga, mis väljendus kognitiivselt ja sotsiaalselt.

Erialane töö on olnud minu jaoks kirg ... Ehk siis see valdkond mind ennast ka tõesti väga huvitab. Ja mind huvitas ka ennast täiendada selles valdkonnas ja seega ka siis neid teadmisi edasi anda õpilastele. (B4)

Õppejõu tööga seoses leiti näiteks, et õpetamine mõjutab pigem nende erialast arengut. Nii kirjeldati intervjuudes olukordi, kus õpetamine on ärgitanud põhjalikumalt tegelema erialaga ning on suunanud erialaselt juurde õppima.

Ma arvan, et ikkagi ma olen palju óppinud juurde oma erialal, just niisuguseid asju, mida mul otseselt töös vaja pole, aga mida ma olen ise uurinud oppetamise pärast. (A4)

Intervjuudes kirjeldati ka erialase töö ja õpetamise erinevusi, nimetades näiteks õppejõu tööd mitte nii keeruliseks kui oma erialase tööga seonduvat. Samuti rõhutasid uuritavad, et nad ei pea ennast õppejõududeks, vaid ennekõike oma eriala esindajateks. Mõnel juhul oli intervjuudes eristatav isegi kahe tegevusala vastandamine sooviga mitte end näidata õppejõudude hulka kuuluvana. Sellele osutasid erinevad väljendid, nagu ma olen rohkem tervishoiutöötaja kui pedagoog ja: 
Ma ei ole nagu päris tüüpiline (õppejõud) selles mõttes. Ma nagu elan klubielu, $N$ klubis. Ma olen ka $N$ ametit pidanud ja tudengitele lugeda loengut on suurusjärk lihtsam kui koosolekut juhatada (A7)

Samas tõdeti, et õpetamine on meeldiv tegevus, kuid seda tehakse pigem vahelduse saamiseks kui vajadusest õpetamise järele.

Mulle see töö (õpetamine) meeldib. Samas ma tean täpselt, et ma iga päev, päevast päeva seda teha ei tahaks, mul on vaheldust vaja. Aga hea meelega ma lähen, ma seisan ópilaste ees ja räägin, kui on vaja ... (C2)

Intervjuudes ilmnesid uuritavate seisukohad oma identiteedi suhtes. Peale selle, et ennast tajuti eriala esindajana, kirjeldati ka oma teekonda erialal ehk jagati meelsasti erialase õppe järgseid töökogemusi erialal, mis lópuks viisid neid õpetamiseni kõrgkoolis.

Kokkuvõttes võib öelda, et praktikute-õppejõudude identiteeti iseloomustas eelkõige tugev seotus oma erialase identiteediga, samas õppejõu identiteeti nii selgelt intervjuudes esile ei toodud. Õppejõutööd peeti oluliseks enesearengu seisukohast, samuti leiti, et see on erialatööst lihtsam ning pakub meeldivat vaheldust igapäevatööle, mistõttu võib öelda, et õppejõu identiteet oli uuritavatel vähe väljendunud.

\section{Eriala- ja õpetamispädevuse teadvustamine}

Kategooriat iseloomustasid väited, mis osutasid erialapädevuse värrtustamisele ja selle esiletoomisele. See, kuidas oma eriala- või õpetamispädevusi mõisteti ja kirjeldati, osutas praktikute-õppejõudude pigem alles kujunevale õpetamispädevusele. Intervjuudes räägiti enamasti erialapädevustest, vähesel määral väljendati õpetamisega seotud kompetentse, mis on küll õpetamispädevuse komponendid, kuid mida ei saa pidada teadlikkuseks õpetamisest kui süsteemsest protsessist ning õpetamise filosoofiast. Intervjuudes osutati õpetamise ja õppimise seostele, sest viidati óppeaine sisu edastamisele ja akadeemilise süsteemi ja praktika seostamisele. Siiski oli õpetamispädevusele viitavate arusaamade esindatus intervjuudes vähe märgatav.

See ongi nü̈d üks uus aspekt, mida ma avastasin hiljuti, mis minu jaoks óppejõu rollis on oluline. Et ma mitte ei ópeta ainult (eriala)sisu, vaid ma õpetan ka selle sisu edastamist ehk vormi ja metodoloogiat. (B4)

Intervjueeritavate hulgas oli ka praktikuid-õppejõude, kes pidasid õpetamispädevusi erialapädevuse osaks ja seotuks ametipositsiooniga (nt juhi ametiga). Samas on oluline märkida, et intervjueeritavad pidasid õpetamise 
kompetentside juures silmas peamiselt selgitust ja informeerimist, mitte õpetamismeetodeid selle mõiste laiemas tähenduses.

Ma ei ole lihtsalt eriala spetsialist, ma olen juht ja juhi üks ülesannetest on ka personali koolitamine, isegi ma tavaliselt juhi rollis ikkagi ópetan, et kuidas ja mida. (C3)

Tulemused osutasid intervjueeritud praktikute-õppejõudude erialapädevuse väljendumisele, mis seisnes nende põhjalikes selgitustes oma erialasest väljaõppest, igapäevasest tööst ja milles toodi esile ka erialase vastutuse ning eetikapiirid. Õpetamispädevuse kirjeldus intervjuudes oli pigem pinnapealne ja üldine. Nii ilmnes intervjuudest uuritavate vähene teadlikkus õpetamise meetoditest ning ka nende kirjeldused õpetamisest olid väga üldsõnalised. Õppejõutööga seotud vastutuse ja eetika teemad praktikute-õppejõudude intervjuudes esile ei tulnud, mis viitab nende erialase identiteedi domineerimisele võrreldes õppejõu omaga.

\section{Seotus eriala- ja õpetamiskogukonnaga}

Kategooriat iseloomustasid peamiselt praktikute-õppejõudude erialakogukonnaga seotusele osutavad tähendused. Uuritavad tõid intervjuudes välja, et nad peavad ennast erialakogukonna liikmeteks. Eriala esindajatena ja erialakogukonna liikmetena väärtustati erialaspetsiifilisi koolitusi ja väljaõpet, samuti kraadiõpet erialal. Kuigi praktikud-õppejõud puutuvad kõrgkoolis õpetades kokku ka teiste õppejõududega, ei nimetatud intervjuudes vajadust õppejõudude kogukonda kuulumise järele ning koostööd teiste kõrgkooli õppejõududega. Kuigi üks võimalus erialakogukonda kuulumiseks on osalemine näiteks õppejõududele pakutavates koolitustes, siis vaid paaris intervjuus tõdeti, et ollakse kõrgkoolide pakutavatest kursustest teadlik. Lisati, et õppejõu töös on teatud õpetamisega seotud nõudmisi, mida nad praktikutena peaksid teadma, kuid eelistavad siiski õpitud erialaga seotud koolitusi. Väga selgelt väljendati arusaama õpetamisest kui kõrvalisest tegevusest, mida tehakse kui erialakogukonna esindaja.

See on nü̈̈d puhtalt minu arvamus, et arvan, see ópetaja on tänapäeval äärmiselt koormatud, ma olen seda tööd kõrvalt ikkagi näinud, kuidas nad ette valmistavad oma tunde, vot minu erialase töö puhul jääb see kõik ära, see pinge, see meeletu pinge, mida ópetajad taluma peavad. (C2)

Külalisõppejõuna olemine on ka see, et pean õppima pedagoogilisi või mingisuguseid nende (kooli) administratiivseid reegleid ikkagi täitma ... jah, see on hea, et viimasel ajal pakutakse kursusi kooli poolt, kuid neid erialaseid on ka nii palju ja valin ikkagi neid ... (B5) 
Õpetamisalase kogukonnaga seotusele viitasid kaudselt arusaamad õpetamisest kui eneseteostuse ja enesearengu võimalustest.

See ópetaja osa on boonuseks pigem, ma ütlen lihtsalt, et midagi ei juhtu ka, kui ma ei ópeta. Aga ma saan ennast kuidagi teostada läbi selle ópetamise. Määratlen ennast ikka ainult põhitöö tegijana oma valdkonnas (C2)

... ma olen ikka eriala valdkonna juht, kes võtab vastutuse suure hulga inimeste ja igapäevaste operatsioonide eest ... tegelikult läbi ôppetöö tegemise ma tunnen, et see võimaldab mind ennast erialal arendada. (A5)

Praktikud-õppejõud tõid välja, et kui nad peaksid valima kahe tegevusala vahel, siis nad loobuksid pigem õpetamisest ja jätkaksid ainult erialapraktikas. Erialapraktikas jätkamise eeliseks peeti eriala arendamise võimalust, õppejõuna eriala arendamise võimalusi ei nimetatud.

Ühel hetkel on see, et kui ma enam ei jaksa, siis kool on esimene, mis kaob mul kõrvalt ära, sest minu jaoks on erialatöö kõige tähtsam, ma tahan seda eriala arendada, et see oleks natuke kõrgemal tasemel, kui meil praegu on (C1)

Kokkuvõtteks võib öelda, et praktikud-õppejõud seostasid intervjuudes end eeskätt oma erialatööga, mida peeti õppejõuna töötamise eelduseks. Intervjuudes väljendati oma kuuluvust erialakogukonda, samas õppejõudude kogukonda kuulumises nähti pigem erialase arengu komponenti või mõjutajat. Seotus õpetamiskogukonnaga ilmnes põgusalt ja intervjuudes ei osutatud ka selle olulisusele.

\section{Praktikute-õppejõudude hübriididentiteedi kujunemisega seotud tegurid}

Andmete analüüsimisel lähtuti praktikute-õppejõudude erialase hübriididentiteedi kujunemisega seotud teguritele osutavatest arusaamadest. Analüüsi aluseks oli kolm kirjanduse ülevaate põhjal loodud kategooriat: eriala- ja õpetamistööga seotud ühiskondlikud normid ja ootused, erialane ja õpetamisalane töökogemus ning erialane ja õpetamisalane ettevalmistus.

\section{Erialase ja õpetamistööga seotud ühiskondlikud normid ja ootused}

Kategooriat iseloomustasid arusaamad, mis seostusid erialase ja õpetamistööga seotud alusdokumentidega, eetiliste tõekspidamiste ja ühiskonna ootustega. Praktikud-õppejõud osutasid intervjuudes peamiselt erialaga seotud 
normidele, ootustele ja eetikale. Intervjuudes toodi välja, et õpetamisel tuginetakse peamiselt erialaga seotud teadmistele, kogemustele ja erialaga seonduvatele ühiskonna ootustele. Õppekavale või teistele õppetööd reguleerivatele dokumentidele osutati intervjuudes põgusalt. Nii kirjeldasid uuritavad, et õpetamisel lähtutakse pigem erialatöö kogemusest ja erialase ettevalmistuse põhjal loodud arusaamadest. Endast õppejõuna räägiti kui valdkonna eksperdist, kes jagab oma kogemusi erialapraktika kohta.

Sellisel juhul ma ei peagi võib olla sellele óppele lähenema niivõrd kui óppejõud, vaid minus saab rohkem avaneda mina kui ekspert, kes ma ju tegelikult olen siia kutsutud ja oodatud oma teadmisi jagama. Et seda ma olen tajunud ja märganud küll ...

Mõned praktikud-õppejõud arvasid, et nende teadmised praktikutena, mida nad erialal õpetades edastavad, on õppekavaga kooskõlas, samas ei selgunud intervjuudest, kas see tõesti õpetamistöös ka nii oli või millel nende sellekohane arvamus põhines.

See kõik, mis on oodatud ja mis see óppekava nagu eeldab, et mul olid need teadmised sisuliselt juba kuskil peas ammu ära formuleeritud ja nad olid paigas praktikast. (C5)

Eriala ja õpetamisega seotud ühiskondlikud normid ja ootused kui identiteeti mõjutavad tegurid tulid intervjuudes esile vähe. Esiplaanil olid erialapraktikast pärit kogemused ja isikliku erialase asjatundlikkuse rõhutamine. Samuti osutasid uuritavate arusaamad sellele, et õpetamistööd mõjutavad erialatöö kogemused, mille põhjal kujundatakse ka oma isiklik õpetamispraktika.

\section{Eriala- ja õpetamistöö kogemus}

Kategooriat iseloomustasid praktikute-õppejõudude arusaamad erialase töökogemuse olulisusest. Nii kirjeldati intervjuudes värvikalt olukordi, kus erialased töökogemused olid andnud ainest õpetamiseks. Praktikud-õppejõud leidsid, et töökogemuse mõjul erialateadmised kinnistuvad ja toetavad neid edaspidi ka õpetamisel. Mitmes intervjuus leiti, et töökogemus erialal annab neile õpetamisel eduelamuse, julguse õpetada ning on ka õppejõuna tegutsemise vajalik eeltingimus.

Pärast loengut tullakse ja tänatakse just nende kogemuste eest, mida nad on minult óppinud ja see on muidugi väga hea tunne, äärmiselt hea tunne, kui sa oled midagi suutnud muuta nendes. (C2) 
Intervjueeritud praktikud-õppejõud leidsid, et pidev töö erialal on väärtus, mis toetab õpetamistegevust. Erialal töötamise tõttu on nende vaade õpetamisele avaram ning erialapraktikas esinevad juhtumid lisavad õppetöösse värskust.

Praktika on see, mis rõhutab kohakaaslase õppejõu väärtust, mina niimoodi arvan. Meil on silmaring laiem, ma arvan, meil on pidev praktikast tulevad värsked juhtumid, värsked arutelud, et see toob särtsu juurde oppuritele ... (C3)

Kokkuvõttes võime öelda, et praktikud-õppejõud tõid intervjuudes välja seoseid erialase töökogemuse ja õpetamistöö vahel. Intervjuudes viidati erialasele töökogemusele kui eeltingimusele õppejõuna tegutsemisel ja peeti eriala õpetamist eelkõige erialatöö kogemuste jagamise võimaluseks.

\section{Erialane ja õpetamisalane ettevalmistus}

Kategooriat iseloomustasid praktikute-õppejõudude arusaamad erialasest ja õpetamisalasest ettevalmistusest. Praktikud-õppejõud olid õpetamisel kogenud olukordi, mis tekitasid neis vastuolulisi tundeid või koguni ebamugavustunnet. Näiteks märgiti õpetamisel kogetud ebakindlust ja ebamugavustunnet inimeste ees esinemisel. Kui enda erialasest ettevalmistusest räägiti kui mõjusast tegurist õpetamise kontekstis, siis õpetamisalasest ettevalmistusest tulenevat mõju intervjuudes selgelt välja ei toodud. Intervjuudes mainiti õpetamisalase ettevalmistuse puudumist ja tõdeti, et õpetamist on pigem ise õpitud.

Õpetamise teoreetilist tausta ei ole mina kuskil mujal óppinud, ainult omal käel. Eneseharimise projekt nii-öelda. (B3)

Mitmel juhul kirjeldati intervjuudes isikuomadusi, mis uuritavate arvates peaksid õppejõule omased või mitteomased olema. Isikuomadusi kirjeldati isiklike õpetamiskogemuste varal ja need osutasid praktikute-õppejõudude teatavale eneserefleksioonile. Uuritavate intervjuudes võrreldi ennast oma kujutluses loodud õppejõule omaste käitumisviiside või isikuomadustega, mis võib osutada kahtlemisele endas kui õppejõus ja mida võib seostada puuduliku õpetamisalase ettevalmistusega. Samas väljendus intervjuudes, et praktikuid soovitakse kõrgkooli õpetama, isegi juhul kui nad ise ennast õpetamisel väga hästi ei tunne.

Avalik esinemine ei ole nagu kunagi olnud asi, mida ma oleks täiel rinnal nautinud, rääkimata sellest, et suuremate rahvahulkade ees esinemine oli ikkagi väga-väga raske. Mõelda ja analüüsida ongi mulle just rohkem sobiv ja 
meelepärane. Siis ma mõtlesin, et ma ei saa ju olla nii halb ópetaja, kui ma ise arvan endast, kui mind pidevalt kutsutakse ja ikkagi tahetakse õpetama. (B6)

Lisaks teatavale sisemisele ambivalentsusele isikuomaduste ja õppejõu rolli vahel nimetati intervjuudes ka oma tegevusi, mida peeti õppejõule mittesobivateks.

Ma olen kohe valmis painduma, kohe valmis vastu tulema, et see ei ole tegelikult óppejõu meetod. Ma pelgan seda, et ma ei ole (õppejõuna) tasemel, ma peaksin olema parem (õppejõuna) ja selle saavutamine on kuidagi vaevaline. (A2)

Uuritavate hulgas oli ka neid, kes hoolimata õpetamisalase ettevalmistuse puudumisest ei kahelnud niivõrd enda õpetamisoskustes, kuivõrd kahtlesid oma erialases ettevalmistuses või erialapraktika piisavuses, mis tekitas nende sõnul ebakindlust ka õpetamisel.

Nü̈̈d on juba palju lihtsam, aga esimesed tunnid ma ikka kartsin. Ma kartsin just seda, et ma ei ole mingisugune tasemel valdkonna spetsialist või midagi sellist. (C1)

Ehkki praktikud-õppejõud tõid erialase ja õpetamisalase ettevalmistuse kontekstis positiivsena esile erialatööga seotud kogemused ja oskused, leiti siiski ka seda, et kui praktikute-õppejõudude osakaal kõrgkooli õppejõudude hulgas on liiga suur, siis võib see seada ohtu kõrgkooli õppetöö kvaliteedi. Näiteks nimetati siin peamise põhjusena praktikute-õppejõudude puudulikku õpetamisalast ettevalmistust.

Ma ei taha öelda, et akadeemilisus oleks vastuolus praktikaga. Ülikooli poolt vaadates, kui suurema osa loengutest peavad mingid spetsialistid, kes pole ülikooli koosseisus, siis see ópetamistaseme ebaühtlus on olemas ja kui ülikool ei taga spetsialistidele mingit ópetajakoolitust ja kontrolli, kuidas need loengud läbi viiakse. Õppetöö kvaliteet võib kannatada. (B3)

Tulemuste põhjal võib esile tuua, et uuritavaid mõjutasid pigem erialast tulenevad dokumendid, normid ja ootused, samas õppejõutööd reguleerivatest dokumentidest, normidest ja nõuetest (nt õppekavad või programmid) räägiti intervjuudes vähesel määral. Kui erialast töökogemust ja ettevalmistust peeti õpetamisel väga oluliseks, siis õpetamisalase ettevalmistuse puudumist enamasti probleemiks ei peetud. Siiski leiti, et tagasihoidlikud õpetamisoskused võivad hakata mõjutama kõrgkooli õppetöö kvaliteeti. 


\section{Arutelu}

Kõrgkoolis õpetamist käsitlevates uuringutes tuuakse välja, et õppejõudude peamine väärtus õppekvaliteedi hoidmisel seisneb eelkõige õppejõudude õpetamisoskustes, võimes siduda teooriat praktikaga, õppijate arendamises ja nende õpiväljundite saavutamise toetamisel (Brower et al., 2017; Fairbrother \& Ford, 1998; Gonzales \& Wagenaar, 2008). Õpetamistöö eeldab võimet teadvustada ennast õppejõuna, aga ka mõista õppejõu identiteeti ja selle kujunemist (Poom-Valickis \& Löfström, 2014).

Kõrgkoolide õpetamispraktikas, kus õppejõul on eelkõige erialane haridus, millele lisandub õpetamiskogemus kõrgkoolis, on praktikud-õppejõud sageli hübriididentiteedi kandjad. Uuringud on näidanud, et õppejõudude õpetamispraktikat ei mõjuta mitte üksnes nende õpetamisarusaamad (Samuelowicz \& Bain, 2001), vaid ka nende eriala ja õpetamisalane identiteet (Poom-Valickis \& Löfström, 2014). Sellist erialast ja õpetamisalast hübriididentiteeti peetakse uuringute kohaselt (Fairbrother \& Ford, 1998; Gonzales \& Wagenaar, 2008) üliõpilaste tulevaste tööoskuste, teadmiste, mõtlemise ja õppijate tulevase erialase identiteedi arendamisel ülioluliseks. Seetõttu seati uuringu eesmärgiks analüüsida praktikute-õppejõudude erialast hübriididentiteeti ja sellega seonduvaid tegureid praktikute-õppejõudude vaates.

Tuginedes erialase identiteedi kujunemise uuringutele, on võimalik erialast identiteeti mõista teatava kognitiivsete tähenduste kogumina, mis on seotud erialase sotsiaalse kontekstiga (nt Stets \& Burke, 2000; Stryker \& Burke, 2000). Erialast identiteeti, mille üheks väljenduseks on erialakogukonda kuuluvuse tunne, on võimalik väljendada eneseanalüüsi kaudu (Luehmann, 2007). Luke ja Goodrich (2010) räägivad erialasest identiteedist kui kognitiiv-psühholoogilisest eneseväljendusest ja näiteks Beijaard jt (2004) vaatlevad erialase identiteedi väljendumist erialase eneserefleksioonina.

Siinse uuringu tulemused osutavad, et praktikute-õppejõudude erialane identiteet on tugevalt seotud oma õpitud erialase kontekstiga - erialakogukonnaga. Õpetamistegevuse eelduseks peetakse peamiselt töötamist oma õpitud erialal. Uuringus osalenud praktikute-õppejõudude identiteeti väljendavad arusaamad olid kooskõlas varasemate uuringute tulemustega, kus tuuakse välja erialase identiteedi väljendamist tööalaste kirjelduste, kogemuste jagamisena (Johnson, Cowin, Wilson, \& Young, 2012) ja erialaga seotud tunnete kirjeldamisena (Johnson et al., 2012; Van Lankveld et al., 2016). Praktikute-õppejõudude arusaamades väljendus nende erialane identiteet kõigis kolmes tunnuses: enesekohases arutelus, erialase kogukonnaga seotuse olulisuse rõhutamises ja erialase maailmavaate esiletoomises, millele osutavad oma uuringus ka Gibson, Dollarhide ja Moss (2010). 
Õpetamises nähakse aga ennekõike tegevust, mis toetab õpitud erialast arengut ehk pigem kujundatakse õpetamise kaudu oma erialast identiteeti. Praktikud-õppejõud peavad õpetamistegevusi ka erialapädevusi toetavaks osaks. Uuringu tulemuste põhjal ei selgunud, kas praktikute-õppejõudude erialane ja õpetamisalane identiteet on hübriidne ehk omavahel põimunud teadmiste, oskuste ja kogemuste seos (nt Reybold, 2008). Tuginedes näiteks Goltzi ja Smithi (2014) uuringule, mille kohaselt hübriididentiteet on mitme eriala pädevuse tunnuste kogum, võib siinse uuringu põhjal arvata, et tegemist on kujuneva hübriididentiteediga, mis on kaldu nn õpitud eriala identiteedi poole. Õppejõu identiteedi vähene väljendumine seisnes uuritavate tähenduslike arvamuste puudumises endast õppejõuna, samuti sooviti õppejõudude kogukonnast pigem eristuda. Lisaks pakkus huvi tulemus, mille kohaselt nägid uuritavad õpetamises oluliselt lihtsamat tegevust kui õpitud erialal töötamist. Nii on väitnud ka Nygren ja Stigbran (2014), et identiteet on väljendatav mitte ainult erialaste väärtuste ja kompetentsidena, vaid ka vastandudes teiste erialade esindajatega. Kuna hübriididentiteet on pidevas kujunemises ja erinevate erialaidentiteetidele omased käitumisviisid domineerivad olenevalt väljakujunemise intensiivsusest (Warin et al., 2006), võib praktikute-õppejõudude hübriididentiteet ollagi kujunemisfaasis, kus õppejõu identiteet veel ei väljendu.

Uuringu tulemused näitasid, et praktikud-õppejõud ei väljendanud vajadust õpetamisalase väljaõppe järele, mida erialase identiteedi arengu kontekstis ei peeta identiteedi arengus vajalikuks mitte üksnes erialateadmiste omandamisel, vaid ka erialakogukonnaga liitumiseks. Tuginedes Smithi ja Boydi (2012) uuringule, kes on toonud välja identiteetide vastuolu problemaatika ja mitme erialase identiteedi kandmise keerukuse, väärib praktikute-õppejõudude tasakaalus hübriididentiteedi kujunemise toetamine eraldi tähelepanu. Nii on varasemad uuringud (nt Smith \& Boyd, 2012) näidanud, et tasakaalustamata erialase hübriididentiteedi ohuks on praktikute lahkumine kõrgkoolist õppejõu töölt täielikult eriala praktikasse. Näiteks Shreeve (2011) on välja toonud, et õppejõuna tegevuse lõpetamine osutab sageli õppejõu identiteedi arengu toetuseta jätmisele. Järelikult peaksid kõrgkoolid praktikute-õppejõudude õpetamistegevuse toetamise kõrval järjest enam tähelepanu pöörama ka õppejõu identiteedi kujunemise toetamisele. Oluline on kaasata praktikuid-õppejõudusid nii õppekavaarendusse kui ka teistesse tegevustesse, mis loovad kuuluvustunnet õppejõudude kogukonnaga. Samuti arusaamist õppejõu tööst, mis ei seisne ainult õpetamises, vaid ka üliõpilaste juhendamises, õppekavaarenduses, uute üliõpilaste vastuvõtus jt tegevustes.

Siinse uuringu tulemused osutasid uuritavate hübriididentiteedile, kus väljendunud erialane identiteet ja vähene õppejõu identiteet võib olla 
õpetamistegevusele määrava mõjuga. Hübriididentiteedi kontekstis võib seda nimetada ka tasakaalustamata hübriididentiteediks, kus teatud identiteet domineerib teise üle. Sellele viitasid eri rollide identiteetidele omased arusaamad ja väljendusviisid (nt Marotta, 2008), mida näiteks Striker ja Burke (2000) selgitavad kui rollide identiteedile omaste tunnuste väljendamist tegevuskontekstis. Tuginedes varasemate ja siinse uuringu tulemusele, võib öelda, et uuringus osalenud praktikute-õppejõudude erialane hübriididentiteet on välja kujunemas, kuigi pigem kaldu eriala identiteedi poole. Väärib esile toomist, et õppejõu identiteet tundub siiski olevat praktikutele-õppejõududele oluline, kuna oma väärtust õppejõuna hinnatakse küll erialapädevuse põhjal, kuid õppejõuna nähakse võimalusi õpitud eriala jätkusuutlikkuseks.

Tuginedes Goltz ja Smith (2014) ja Stryker ja Burke (2000) erialase identiteedi tõlgendusele, on erialane identiteet mõjutatud sotsiaalsetest ja personaalsetest teguritest. Sotsiaalselt mõjutavad erialast identiteeti ühiskondlikud normid, ootused ja riiklikud regulatsioonid (sh õppekavad ja pädevusnõuded). Personaalsed faktorid on pigem seotud eriala teadvustamise ja rollikujutlusega. Erialase identiteedi arengus on sotsiaalsete ja personaalsete tegurite võrdväärne mõju identiteedile oluline. Need tegurid kujundavad eriala sotsiaalse tunnustuse ja mõjususe ühiskonnas (nt Murray, 2013). Erialase identiteedi kujunemist mõjutavate teguritena on varasemates uuringutes nimetatud ka erialal töötamise kogemusi (nt Crossey \& Vivekananda- Schmidt, 2009; Gibson et al., 2010; Goltz \& Smith, 2014).

Uuringu tulemuste põhjal saab öelda, et õpetamisalase väljaõppe puudumine on õppejõu identiteedi kujunemist mõjutava tegurina olulisel kohal. Näiteks Goltz ja Smith (2014) ning Nygren ja Stigband (2014) on leidnud, et erialast identiteeti kujundatakse erialaste õpingute, õppejõudude ja praktikajuhendajate mõjul. Uuringu tulemused osutasid mitmele praktikute-õppejõudude erialase identiteedi kujunemist toetavale tegurile, nagu erialane õpe ja praktika, erialase teaduskraadi omandamine. Samal ajal õppejõu identiteeti mõjutavatele teguritele osutamine oli tagasihoidlik ja tulemused viitavad pigem õpetamise iseõppimisele.

Tulemuste põhjal saab esile tuua, et praktikute-õppejõudude hübriididentiteedi kujunemisele on mõju avaldanud erialane haridus, töökogemus ja õpetamistegevus, seda just õpitud erialase identiteedi suhtes. Õppejõu identiteedi kujunemist on takistanud õpetamiskogukonda kaasatus, mis on seotud nii väljaõppe kui ka kogukonda kuuluvuse toetamisega. Võimalik, et kuuluvust erialakogukonda tajutakse nn kõrgema staatusena kui õppejõuks olemist, seetõttu defineeritakse ennast eriala praktikuna ehk selle eriala järgi, mis staatust tõstab. Toetudes näiteks Marotta (2008) kirjeldusele hübriididentiteedist kui eri rolliidentiteetide kujunemise protsessist, saab siinse uuringu põhjal 
mõista praktikute-õppejõudude hübriididentiteeti pigem rolliidentiteetide kujunemisena.

Kuna tasakaalus erialase hübriididentiteedi kujunemisel on mitu mõjutegurit, võimaldab teadlikkus nendest toetada praktikute-õppejõudude hübriididentiteedi kujunemist. Tasakaalus hübriididentiteet kujundab praktikute-õppejõudude õpetamiskvaliteeti, väärtustades samal ajal erialakogemusi, nende lõimimist õppetöösse, jätmata praktikuid-õppejõudusid eraldatusse, nagu on välja toonud oma uurimuses ka Masri (2018).

Erialase hariduse mõju praktikute-õppejõudude identiteedile on uurimistöö tulemuste põhjal kõige selgemini väljendunud ja õpetamisalase ettevalmistuse puudumine identiteedi kujunemisele nende arusaamades märgatav. Praktikute-õppejõudude õpetamispraktika on kujunenud paljuski iseõppimise teel, mitte süsteemsele väljaõppele tuginedes. Seega võib öelda, et tugev kuuluvus erialakogukonda, õppejõu identiteedi arengut mõjutavate tegurite puudumine, sealhulgas õppejõudude kogukonda kuuluvuse puudumine, on praktikute-õppejõudude tasakaalustamata hübriididentiteedi kujunemisel määrava tähtsusega.

Uuringu piirangud on seotud eelkõige valimi suuruse ja koosseisuga: tulemused põhinevad nelja eriala esindajatega tehtud intervjuudel. Tulemusi võisid mõnevõrra mõjutada intervjuu küsimused, milles ei arutletud praktikute-õppejõududega otseselt erialase identiteedi teemal, vaid intervjuude keskmes olid praktikute-õppejõudude arusaamad eriala ja õpetamispraktika kontekstis. Ka on praktikud-õppejõud eelkõige seotud oma erialatööga, õpetades kõrgkoolis vaid ajutiselt, seepärast võis nende eneseväljendus olla mõnevõrra raskendatud õpetamisalase terminoloogia vähese tundmise tõttu. Praktikute-õppejõudude uurimine vajab aga edaspidigi tähelepanu, kuna nende panus kõrgharidusse on peale erialateadmiste ja oskuste oluline ka tulevaste spetsialistide erialaidentiteedi kujundamisel. Praktikute-õppejõudude erialase hübriididentiteedi uurimine, toetamine ja kujundamine on tähtis, et tagada nende jätkuv osalemine kõrgkoolide õppetöös ja seega ka kõrghariduse kvaliteedi kujundamisel.

Kuigi uuringu tulemuste põhjal ei ole võimalik teha üldistusi, on tulemused siiski mõtlemapanevad ja võiksid huvi pakkuda nii kõrgkoolides õppetööd korraldavatele spetsialistidele kui ka organisatsioonide juhtivtöötajatele praktikute kõrgkoolidesse värbamisel. Praktikute-õppejõudude tasakaalus erialane hübriididentiteet rikastab ja toetab kõrgkoolide õppetööd, tagades samal ajal ka kõrgkoolide õpetamiskvaliteedile esitatud nõuded. Samuti võib tulemuste põhjal väita, et praktikud-õppejõud on oma õpetamiskogemuse mõjul unikaalse erialase identiteedi tõttu väärtuslikud töötajad erialapraktikas ja erialaorganisatsioonide arendustegevuses. 


\section{Kasutatud kirjandus}

Barbour, J. B., \& Lammers, J. C. (2014). Measuring professional identity: a review of the literature and a multilevel confirmatory factor analysis of professional identity constructs. Journal of Professions and Organization, 2(1), 38-60. https://doi.org/10.1093/jpo/jou009

Beijaard, D., Meijer, P.C., \& Verloop, N. (2004). Reconsidering research on teachers' professional identity. Teaching and Teacher Education 20(2), 107-128. https://doi.org/10.1016/j.tate.2003.07.001

Bilgrami, A. (2001). Identity and identification: philosophical aspects. In N. Smelser and P. B. Baltes (Eds.), International Encyclopedia of the Social \& Behavioral Sciences (pp. 149-154). Amsterdam: Elsevier.

Brower, A.M., Humphreys, D., Karoff, R., \& Kallio, S. (2017). Designing quality into direct-assessment competency-based education. The Journal of CompetencyBased Education 2(2). 1-10. https://doi.org/10.1002/cbe2.1043

Brubaker, R., \& Cooper, F. (2000). Beyond „identity“. Theory and Society, 29, 1-47. https://doi.org/10.1023/A:1007068714468

Colley, H., \& Guery, F. (2014). Understanding new hybrid professions: Bourdieu, illusio and the case of public service interpreters. Cambridge Journal of Education, 45(1), 113-131. https://doi.org/10.1080/0305764X.2014.991277

Correa, J. M., Martinez-Arbelais, A., \& Gutierres, L. P. (2014) Between the real school and the ideal school: another step in building a teaching identity. Journal Educational Review 66(4), 447-464. https://doi.org/10.1080/00131911.2013.800956

Crossley, J,. \& Vivecananda-Schmidt, P. (2009). The development and evaluation of a Professional Self Identity Questionnaire to measure evolving professional selfidentity in health and social care students. Medical Teacher, 31(12), e603-e607. https://doi.org/10.3109/01421590903193547

Dall'Alba, G. (1994). The role of teaching in higher education: Enabling students to enter a field of study and practice. Learning and Instruction, 3(4), 299-313. https://doi.org/10.1016/0959-4752(93)90021-Q

Ehala, M. (2018, 22. juuni). Mis identiteet õigupoolest ikkagi on? Sirp.

Elo, S., \& Kyngäs, H. (2008). The qualitative content analysis process. Journal of Advanced Nursing, 62(1), 107-115. https://doi.org/10.1111/j.1365-2648.2007.04569.x

Elo, S., Kääriäinen, M., Kanste, O., Pölkki, T., Utriainen, K., Kyngäs, H. (2014). Qualitative content analysis: a focus on trustworthiness. SAGE open. January-March, 1-10. https://doi.org/10.1177/2158244014522633

Fairbrother, P., \& Ford, S. (1998). Lecturer practitioners: a literature review. Journal of Advanced Nursing Volume 27(2). 274-279. https://doi.org/10.1046/j.1365-2648.1998.00525.x

Fairbrother, P., \& Mathers, N.J.(2004). Lecturer practitioners in six professions: combining cultures. Journal of Clinical Nursing, 13(5), 539-546 https://doi.org/10.1111/j.1365-2702.2004.00907.x

Fejes. A., \& Köpsén; S. (2014). Vocational teachers' identity formation through boundary crossing. Journal of Education and Work, 27(3), 265-283. https://doi.org/10.1080/13639080.2012.742181 
Fitzmaurice, M. (2013) Constructing professional identity as a new academic: a moral endeavour. Studies in Higher Education 38(4), 613-622. https://doi.org/10.1080/03075079.2011.594501

Gibson, D. M., Dollarhide, C. T., \& Moss, J. M. (2010). Professional identity development: A grounded theory of transformational tasks of new counselors. Counselor. Education and Supervision 50(1), 21-38. https://doi.org/10.1002/j.1556-6978.2010.tb00106.x

Gleason, P. (1983). Identifying identity: a semantic history. The Journal of American History, 69(4), 910-931. https://doi.org/10.2307/1901196

Goltz, H. H., \& Smith, M. L.(2014). Forming and Developing Your Professional Identity: Easy as PI. Health promotion practice, 15(4), 785-789. https://doi.org/10.1177/1524839914541279

Gonzáles, J., \& Wagenaar, R. (Eds.) (2008). Universities' contribution to the Bologna Process (2nd ed.). Spain: Bilbao.

Gourlay, L. (2011). New lecturers and the myth of „communities of practice“. Studies in Continuing Education, 33(1), 67-77. https://doi.org/10.1080/0158037X.2010.515570

Graneheim, U. H., \& Lundman, B. (2004). Qualitative content analysis in nursing research: Concepts, procedures, and measures to achieve trustworthiness. Nurse Education Today, 24(2), 105-112. https://doi.org/10.1016/j.nedt.2003.10.001

Helmich, E., Derksen, E., Pervo, M., Laan, R., Bolhuis, S., \& Koopmans, R. (2010). Medical students' professional identity development in an early nursing attachment. Medical Education, 44(7), 674-682. https://doi.org/10.1111/j.1365-2923.2010.03710.x

Hope, J. (2018). SRHE final project report: dual professionals in higher education: from professional practitioner to lecturer. SRHE Newer Researcher. Külastatud aadressil https://www.srhe.ac.uk/downloads/reports-2018/SRHE-Final-ReportJulia-Hope-2020.pdf

Jenkins, R. (2000). Categorization: identity, social process and epistemology. Current Sociology, 48(3), 7-25. https://doi.org/10.1177/0011392100048003003

Johns, C. (2004). Becoming a Reflective Practitioner. UK: Blackwell Publishing.

Johnson, M., Cowin, L, S., Wilson, I., \& Young, H. (2012). Professional identity and nursing: contemporary theoretical developments and future research challenges. International Nursing Review, 59(4), 562-569 https://doi.org/10.1111/j.1466-7657.2012.01013.x

Khatoon, S., \& Usmani, M.A.W. (2014) Effectiveness of program evaluation through the HEC prescribed self-assessment model in improving the quality of degree programs in a public sector university in Pakistan. International Journal of Physical and Social Sciences 4(1), 42-72.

Levin, J. S., \& Shaker, G. G. (2011). The Hybrid and dualistic identity of full-time non-tenure-track faculty. American Behavioral Scientist, 55(11), 1461-1484. https://doi.org/10.1177/0002764211409382

Limberg, D., Bell, H., Super, J. T., Jacobson, L., Fox, J., DePue, M. K., Christmas, C., Young, M. E., \& Lambie, G. W. (2013) Professional identity development of counselor education doctoral students: a qualitative investigation. Professional Counselor, 3(1), 40-53. 
Lin, E., Shi, Q., Wang, J., Zhang, S., \& Hui, L. (2012). Initial motivation for teaching: Comparison between preservice teachers in the United States and China. AsiaPacific Journal of Teacher Education, 40(3), 227-248. https://doi.org/10.1080/1359866X.2012.700047

Luehmann, A. L. (2007). Identity development as a lens to science teacher preparation. Science Education, 91(5), 822-839. https://doi.org/10.1002/sce.20209

Luhrmann, T. M. (2001). Identity in anthropology. In N. J. Smelser, P. B. Baltes (Eds.), International Encyclopedia of the Social \& Behavioral Sciences. (pp. 7154-7159). Amsterdam: Elsevier. https://doi.org/10.1016/B0-08-043076-7/00891-3

Luke, M., \& Goodrich, K. M. (2010). Chi sigma iota chapter leadership and professional identity development in early career counselors. Councelor. Education and Supervision, 50(1), 56-78. https://doi.org/10.1002/j.1556-6978.2010.tb00108.x

Marcelo, C. 2009; Professional Development of Teachers: past and future. Sísifo/ Educational Sciences Journal, 8(9), 5-20.

Marotta, V. P. (2008). The hybrid self and the ambivalence of boundaries. Social identities, 14 (3), 295-312. https://doi.org/10.1080/13504630802088052

Masri, T, I. (2018). The professional identity of adjunct faculty: exploratory study at privat university in UAE. English Language Teaching, 11(10), 16-29. https://doi.org/10.5539/elt.v11n10p16

Monrouxe, L. V.(2010). Identity, identification and medical education: why should we care? Medical Education, 44(1),40-49. https://doi.org/10.1111/j.1365-2923.2009.03440.x

Murray, J. (2013). Becoming an early years professional: developing a new professional identity. European early childhood education research journal, 21(4), 527540. https://doi.org/10.1080/1350293X.2013.845441

Nygren, G., \& Stigbran, K. (2014). The formation of a professional identity. Journalism Studies,15(6), 841-858. https://doi.org/10.1080/1461670X.2013.834163

Poom-Valickis, K., \& Löfström, E. (2014) Pikiuuring õpetajaks õppijate professionaalse identiteedi kujunemisest. Eesti Haridusteaduste Ajakiri, 2(1), 241-271. https://doi.org/10.12697/eha.2014.2.1.10

Reva, E., Karm, M., Lepp, L., \& Remmik, M. (2014). Praktikute-õppejõudude õpetamisarusaamad rakenduskõrgkoolis. Eesti Haridusteaduste Ajakiri, 2(2), 116147. https://doi.org/10.12697/eha.2014.2.2.05

Reybold, L. E., (2008). Practitioner-faculty dialectic: balancing professional identities in adult education. Journal of Adult Development, 15(3), 140-147. https://doi.org/10.1007/s10804-008-9045-8

Robinson, M., \& McMillan, W. (2006) Who teaches the teachers? Identity, discourse and policy in higher education. Teaching and Teacher Education, 22, 327-336. https://doi.org/10.1016/j.tate.2005.11.003

Shreeve, A. (2011). Being in two camps: Conflicting experiences for practice-based academics. Studies in Continuing Education, 33(1), 79-91. https://doi.org/10.1080/0158037X.2011.521681

Slay, H. S., \& Smith, D. A. (2011). Professional identity construction: Using narrative to understand the negotiation of professional and stigmatized cultural identities. Human Relations, 64(1), 85-107. https://doi.org/10.1177/0018726710384290 
Smith, C., \& Boyd, P. (2012). Becoming an academic: The reconstruction of identity by recently appointed lecturers in nursing, midwifery and the allied health professions. Innovations in Education and Teaching International, 49(1), 63-72. https://doi.org/10.1080/14703297.2012.647784

Stets, J. E. \& Burke, P. J. (2000). Identity Theory and Social Identity Theory. Social Psychology Quarterly, 63(3), 224-237. https://doi.org/10.2307/2695870

Stryker, S. \& Burke, P. (2000). The past, present, and future of an identity theory. Social Psychology Quarterly, 63(4), 284-297. https://doi.org/10.2307/2695840

Valk, A. (2003). Identiteet. J. Allik, A. Raelo, K. Konstabel (toim). Isiksuse psühholoogia (lk 225-250). Tartu: Tartu Ülikooli Kirjastus.

Van Lankveld, T., Schoonenboom, J., Kusurkar, R. A., Volman, M., Bieshuizen, J., \& Croiset, G. (2016). Integrating the teaching role into one's identity: a qualitative study of beginning undergraduate medical teachers. Advances in Health Sciences Education, 22(3), 601-622. https://doi.org/10.1007/s10459-016-9694-5

Vermunt, J. D., \& Verloop, N. (1999). Congruence and friction between learning and teaching. Learning and Instruction 9(3), 257-280. https://doi.org/10.1016/S0959-4752(98)00028-0

Warin, J., Maddock, M., Pell, A., \& Hargreaves, L. (2006). Resolving identity dissonance through reflective and reflexive practice in teaching. Reflective Practice, 7(2), 233-245. https://doi.org/10.1080/14623940600688670 


\title{
The understandings of practitioner-lecturers on professional hybrid-identity
}

\author{
Elina Reva ${ }^{\mathrm{a}}$, Marvi Remmik \\ ${ }^{a}$ North Estonia Medical Centre, Tallinn Health Care College \\ ${ }^{b}$ Johan Skytte Institute of Political Studies, University of Tartu \\ Viljandi Culture Academy
}

\section{Summary}

\section{Introduction}

Higher education in Estonia is changing along with the developments taking place in the European Union and now. There is a need to involve practitioners who are capable of offering a high-quality teaching service in higher education institutions. This article concentrates on the practitioner-lecturers who are specialists in their fields and, at the same time, teach at schools according to the established curricula.

The success of a teaching practice is determined by a lecturer's professional identity, its development and manifestation. Thus, the practitioner-lecturers who continue working in their field of study and also teach at a higher education institution, may have a very unique professional identity.

Researchers consider the concept of identity to be very broad (e.g. Brubaker \& Cooper, 2000; Jenkins, 2000) and the borders of the term vague, and no consensus of the content has been reached (Ehala, 2018). Generally, identity is believed to be one part of the human self-concept which is developed in a mutual relationship with other individuals.

In the context of professional development, the topics mostly discussed are identities linked to human roles, including professional identity and hybrididentity. Based on the definition by Goltz and Smith (2014), professional identity is linked to both external (deriving from environment) and internal (deriving from personality) actors. The development of a professional identity is in constant change. It is a dynamic process, a reality that evolves at an individual as well as social level (Correa et al., 2014; Marcelo, 2009).

Hybrid-identity is widely (Goltz \& Smith, 2014) in the context of professional development, which forms an entity due to the joining of two or more important professional roles. In this entity, the roles themselves bear various

North Estonia Medical Centre, Sütiste 19, Tallinn, 13419 Estonia;

elina.reva@regionaalhaigla.ee 
identities (Shreeve, 2009). Two professional identities are interrelated by knowledge, as well as practical and professional experience (Reybold, 2008). There is one thing characteristic to the development of a dynamic professional hybrid-identity. The behaviour of one professional identity will prevail while another professional identity evolves (Warin et al., 2006). Thus, the development of a professional hybrid-identity is actually a process of changing professional identities. It is a sort of psychological dissonance that is witnessed in a discomforting situation (Warin et al., 2006).

The development of a hybrid-identity of a practitioner-lecturer may turn out especially disrupting due to the need to link two work cultures and accept the differences between them. This requires positive psychological support and support from the environment. Without the presence of such actors, the professional hybrid-identity is out of balance. This may at times result in the decision not to work as a lecturer anymore and return to professional work (Smith \& Boyd, 2012). Usually the latter shows that the development of a lecturer's professional identity lacks support or has stopped for some reason (Shreeve, 2009).

Being aware of the essence of the hybrid-identity of a practitioner-lecturer is important in the context of teaching practices. It is important for the development of the identities of future professionals, as well as for supporting the professional identity development of practitioner-lecturers. In order to shape and develop the teaching practices of practitioner-lecturers via developing their professional identity, it is necessary to understand the professional (hybrid) identity of these practitioner-lecturers and the actors shaping it in their understandings.

The aim of the study is to determine how the professional hybrid-identity is manifested in the view of practitioner-lecturers and what affects its development. Based on the aim, the following research questions were addressed:

1. How is the professional hybrid-identity manifested in the view of practitioner-lecturers?

2. What factors do practitioner-lecturers point out as affecting the evolvement of their professional (hybrid) identity?

\section{Study design and selection of the subject}

The study was carried out among 18 practitioner-lecturers. Next to their daily vocational work, they also taught at Estonian higher technical colleges in social, healthcare or technology fields. The sample was comprised intentionally. During the period of data collection, the subjects were working full-time in their field of profession and half-time teaching. The work experience of the subjects varied between 3 and 45 years, and their teaching experience between 
0.5 and 45 years. The workload of practitioner-lecturers at a higher education institution was on average 78 academic hours per school year. For data collection, semi-structured interviews were conducted with practitioner-lecturers. Hence, a plan for a semi-structured interview was drawn. In these interviews, the focus was on teaching practices of practitioner-lecturers.

After the interview plan was finalised, experts in their fields were asked to specify and complement the questions. Once the questions had been modified, a test interview was carried out with two practitioner-lecturers.

Following the test interview, no crucial changes were made to the interview plan. The transcript per interview took up approximately seven pages and the total of transcribed material was 105 pages. To analyse the data, qualitative deductive content analysis was used. The latter was led by a theoretical overview of previous studies and findings. A framework of categories was formed as a basis of the data analysis. The framework itself was based on the literature overview, which was used to categorise the most relevant and characteristic meaning units from the interviews. Based on the data analysis, meaning units were distinguished.

\section{Results}

The study results revealed that the practitioner-lecturers expressed a strong bond to their vocational work, which was also their main field of activity main job. Working in their profession was seen as the prerequisite and basis for their teaching related work. The advocated understandings were in accordance with the previous study findings. The latter emphasise the descriptions of work-related positions and experience that appear when expressing professional identity.

The vocational belongingness was evident in the understandings of practitioner-lecturers, whereas the teaching-related belongingness was not deeply expressed. Being connected to the teaching community was briefly mentioned and the practitioner-lecturers did not express its importance. Also, the weak connection between the teaching community and practitioner-lecturers was illustrated by the lack of topic-related meaningful opinions, differentiating from the teaching community or even being opposed to the latter. The findings of the study indicate that practitioner-lecturers perceive themselves as practitioners in a higher status and therefore define themselves as practitioners. The results do not refer directly to the professional and teaching-related hybrid-identity of practitioner-lecturers but do refer to its evolving. The practitioner-lecturers' identity can also be called a complex identity, because it is multifaceted and unique. 
There are many affecting actors in the evolving of a balanced professional hybrid-identity. On the one hand, understanding the affecting factors enables to support the evolving of the hybrid-identity of practitioner-lecturers. This, on the other hand, reduces the inconsistencies in professional work and teaching, affecting teaching quality. During the interviews with practitioner-lecturers the effect of the professional work experience on teaching, which also had an impact on the hybrid-identity, became obvious. The effect of professional education on the development of the identity was visible in the appearance and importance of the professional competence of practitioner-lecturers.

The influence of teaching-related education was not expressed in the interviews. The practitioner-lecturers rather expressed their knowledge on what the necessary and unnecessary characteristics of lecturers include. As they did not point to actors supporting teaching, this hints at a hybrid-identity, which is currently in the process of developing or unbalanced. It deserves to be highlighted that the practitioner-lecturers believe the lecturer's identity to be important, because practitioner-lecturers value their success as lecturers thanks to their vocational competence. It is also important to point out that the practitioner-lecturers' identity development is also taking place thanks to the teaching practice. Hence, due to the original hybrid-identity, practitionerlecturers are also valuable to their field of profession.

Keywords: practitioner-teachers, professional identity, professional hybrididentity, qualitative study 